\title{
Assessment of In Vitro Antioxidant and Anti-Inflammatory Potentials of Methanol Ex- tract of Chrysophyllum albidum Cotyledon
}

\author{
Christianah A. Dare $^{1^{*}}$ and Nelson O. Elvis ${ }^{1}$ \\ ${ }^{1}$ Department of Biochemistry, Osun State University, Osogbo, Osun State. Nigeria.
}

\begin{abstract}
*Correspondence should be addressed to Christianah A. Dare: bimpeoasis@yahoo.com
Received 6th November 2020; Revised 21st December 2020; Accepted 23rd December 2020

(C) 2020 Dare and Elvis . Licensee Pan African Journal of Life Sciences. This is an Open Access article distributed under the terms of the Creative commons Attribution License (https://creativecommons.org/licenses/BY/4.0), which permits unrestricted use, distribution, and reproduction in any medium, provided the original work is properly cited.
\end{abstract}

\begin{abstract}
Background: This study was aimed at analysing the phytochemicals in Chrysophyllum albidum cotyledon extract and their in vitro antioxidant and anti-inflammatory effects.

Methods: The Chrysophyllum albidum cotyledon methanol extract (CCME) was phytochemically screened, and flavonoids and phenol contents, antioxidant and anti-inflammatory assays were carried out on the extract using standard procedures.

Results: Phytochemicals analysis revealed the presence of steroids, tannins, flavonoid, saponin, triterpenes and xanthoproteins. The phenolic concentration, total flavonoids concentration and sugar concentration were found to be 26.720.048 $\mu \mathrm{g}$ of Tannic Acid Equivalent (TAE /mg, 23.121.92 $\mu \mathrm{g}$ of Rutin Equivalent (RTE)/mg (10.491.12 $\mu \mathrm{g}$ of Quercetin Equivalent (QE)/mg) and 778.3812.82 $\mu \mathrm{g}$ of glucose $/ \mathrm{ml}$ respectively. The extract demonstrated significant $(\mathrm{P}<0.05)$ inhibitory effect compared with the standards as potent antioxidant with DPPH $\mathrm{IC}_{50}$ of $550.52 \pm 82.83 \mu \mathrm{g} / \mathrm{ml}$, lipid peroxidation $(45.85 \%-65.85 \%)$, Ferric reducing power showed linear correlation to the standard and the anti-inflammatory potential with $(22.06 \%-26.37 \%)$ percentage protection of the human red blood membrane stability and the percentage inhibition of denaturation of albumin $(3.42 \%-7.32 \%)$.

Conclusion: The study showed that $C$. albidum cotyledon methanol extract is a potent antioxidant and anti-inflammatory agent to oxidative stress and pathological disease caused by reactive species.
\end{abstract}

Keywords: Phytochemicals, plant, pharmaceuticals, oxidative stress, pathological disease, scavenger 


\subsection{INTRODUCTION}

Naturally occurring substances are of plants, animals and mineral origin. They are organic substances and could be obtained in both primary and secondary metabolic process; they also provide a source of medicine since the earliest time [1]. The plant kingdom has proven to be the most useful in the treatment of diseases and they provide an important source of all the world's pharmaceuticals. The most important of these bioactive constituents of plants are steroids, terpenoids, carotenoids, flavonoids, alkaloids, tannins and glycosides. Plants in all facets of life have served a valuable starting material for drug development [2].

Despite technologic advances, the drug discovery process is facing a major innovation deficit that is adversely affecting the pharmaceutics industry [3,4]. Drug discovery based on ethnopharmacology and use of natural products keep gaining momentum in the current world order where the poor remains at the receiving end due to the problem of affordability and accessibility [5]. It is also a known fact that many modern drugs have their origin in ethnopharmacology and this has fuelled research in the direction of ethnomedicine and natural product research [6].

Oxidative stress, whose end result is the generation of free radicals and reactive species, has been implicated in the largest percentage of most dangerous diseases. Antioxidants are agents that help in mopping up these dangerous chemicals and the search for antioxidant and anti-inflammatory agents cannot be overemphasised [7].

C. albidum is a local fruit that is consumed mostly in Africa. Nevertheless, the seed is discarded afterwards and considered a waste. There have been various scientific evidences of great medicinal values of seeds and this necessitated this research to check for the antioxidant and anti-inflammatory potentials that could be exploited in this so-called waste.

\subsection{METHODOLOGY}

\subsection{Preparation of Methanol Extract of C. albidum}

C. albidum fruits were purchased from Igbona market Osogbo, Osun State, Nigeria $\left(07^{0} 46^{\prime} 51^{\prime \prime} \mathrm{N}, 04^{0} 33^{\prime} 28^{\prime \prime}\right.$

E) and authenticated at Department of Plant Biology, Osun State University, Osun State, Nigeria. Seeds were removed from star apple (C. albidum) fruits and broken to obtain the cotyledon. The cotyledon was air dried and blended with a blender to increase the surface area before it was defatted with hexane using soxhlet extraction method. The defatted residue was then exhaustively extracted with methanol and the filtrate was concentrated to dryness using Edman High Vacuum Pump under reduced pressure at $45^{\circ} \mathrm{C}$ to obtain C. albidum cotyledon methanol extract (CCME) used for this research work.

\subsection{Phytochemical Screening}

The CCME was screened for the presence of secondary metabolites such as flavonoids, tannins, saponins, anthraquinones, terpenoids according to standard procedures $[8,9,10]$.

\subsubsection{Test for Steroids}

The extract $(0.5 \mathrm{~g})$ was dissolved in water $(5 \mathrm{ml})$. Concentrated sulphuric acid $(1.0 \mathrm{ml})$ was added to $1 \mathrm{ml}$ of aqueous extract, and allowed to stand for $5 \mathrm{~min}$. Colour change from violet to blue or green in the sample indicated the presence of steroids. The control contained everything above except the sample replaced with equal amount of distilled water.

\subsubsection{Test for Tannins}

CCME (10 mg) was dissolved in $10.0 \mathrm{ml}$ distilled water and filtered. To $1.0 \mathrm{ml}$ of the filtrate in triplicate, few drops of $0.5 \mathrm{M}$ Ferric chloride in glacial acetic were added. The mixture was observed for the formation of blue, green or blue black colouration or precipitate. The control contained everything above except the sample replaced with equal amount of distilled water.

\subsubsection{Test for Phlobatannins}

The extract $(0.5 \mathrm{~g})$ was boiled with $10 \%(\mathrm{v} / \mathrm{v}) \mathrm{HCl}$, formation of a red precipitate was observed as evidence for the presence of phlobatanins.

\subsubsection{Test for Flavonoids}

(a) CCME $(5.0 \mathrm{mg}$ ) was dissolved in $5.0 \mathrm{ml}$ ethanol, shook and filtered. Few drops of $0.5 \mathrm{~N}$ ethanolic potassium hydroxide solution were added to $1.0 \mathrm{ml}$ of the filtrate in triplicate. The mixture was observed for the formation of yellowish suspension, precipitate or both.

(b) CCME $(0.1 \mathrm{~g})$ was suspended in $5.0 \mathrm{ml}$ of ethyl acetate, shaken vigorously and filtered. To $1.0 \mathrm{ml}$ of the filtrate was added a few drops of dilute ammonia 
solution. A colour change (pink or deep brown) in the alkaline layer was observed. The control contained everything above except the sample replaced with equal amount of distilled water.

\subsubsection{Test for Saponins: Frothing Test}

CCME $(100.0 \mathrm{mg}$ ) was dissolved in $2.0 \mathrm{ml}$ of distilled water in a clean test tube and shaken vigorously for a persistent froth formation. The reaction mixture was warmed gently and shaken vigorously and observed for persistent frothing. The control contained everything above except the sample replaced with equal amount of distilled water.

\subsubsection{Test for Anthraquinone}

CCME $(0.5 \mathrm{~g})$ was suspended in $2.0 \mathrm{ml}$ dilute sulphuric acid $(1 \% \mathrm{v} / \mathrm{v})$ and filtered to reduce the turbidity. The filtrate was shaken with benzene $(2.5 \mathrm{ml})$, the benzene layer was separated and $2.0 \mathrm{ml}$ of $10 \%$ (v/v) ammonia solution was added. The reaction mixture was observed for the formation of red colouration at ammonia layer. The control contained everything above except the sample replaced with equal amount of distilled water.

\subsubsection{Test for Triterpenes}

CCME (20 mg) was suspended in $10.0 \mathrm{ml}$ chloroform, warmed slightly in water bath and then filtered and 5.0 $\mathrm{ml}$ of conc. sulphuric acid was added to the chloroform filtrate and mixed properly. The reaction mixture was observed for the formation of red colour indicating the presence of triterpenes. The control contained everything above except the sample replaced with equal amount of distilled water.

\subsubsection{Test for Xanthoproteins}

CCME $(0.5 \mathrm{~g})$ was suspended in $2.0 \mathrm{ml}$ distilled water and filtered. To $1.0 \mathrm{ml}$ of the filtrate, few drops of nitric acid and few drops of ammonia solution were added. The reaction mixture was observed for the formation of red colour. The control contained everything above except the sample replaced with equal amount of distilled water.

\subsection{Quantitative Analysis of Antioxidative Components}

\subsubsection{Estimation of Total Phenol (TPH) Concentration}

The total phenol content in CCME was determined according to the method of Singleton et al., [11]. The standard calibration curve of tannic acid was prepared by pipetting $1 \mathrm{ml}$ of tannic acid solution $(0,10 \mu \mathrm{g} / \mathrm{ml}, 20 \mu \mathrm{g} /$ $\mathrm{ml}, 30 \mu \mathrm{g} / \mathrm{ml}, 40 \mu \mathrm{g} / \mathrm{ml}$ and $50 \mu \mathrm{g} / \mathrm{ml}$ of tannic acid) in triplicate into clean and dried test tubes. To each of the tubes was added $1.5 \mathrm{ml}$ of Folin-Ciocalteu's phenol reagent (1:10 dilution). The reaction mixtures were incubated at room temperature for 5 minutes followed by the addition of $1.5 \mathrm{ml}$ of $7.5 \%(\mathrm{w} / \mathrm{v}) \mathrm{Na}_{2} \mathrm{CO}_{3}$ solution. The reaction mixtures were further incubated for 1 hour 30 minutes at room temperature. The absorbance was read at $725 \mathrm{~nm}$ against the reagent blank. The standard calibration curve was prepared by plotting the absorbance against tannic acid concentrations. The estimation of phenol content in CCME was carried out by pipetting 0.5 $\mathrm{ml}$ and $1 \mathrm{ml}$ of $1 \mathrm{mg} / \mathrm{ml}$ of the extracts in triplicates. The volumes of the extracts were adjusted to $1.0 \mathrm{ml}$ with distilled water. The reaction was treated as above. The total phenol concentration of CCME was interpolated from the standard calibration curve and expressed as mg tannic acid equivalent per $g$ of extract (mg TAE/ $g$ extract).

\subsubsection{Estimation of Total Flavonoid (TFL) Concentration}

The total flavonoid content CCME was determined according to the method described by Sun et al., [12]. The standard calibration curve of rutin and quercetin was prepared $(0 \mu \mathrm{g} / \mathrm{ml}, 20 \mu \mathrm{g} / \mathrm{ml}, 40 \mu \mathrm{g} / \mathrm{ml}, 60 \mu \mathrm{g} / \mathrm{ml}, 80 \mu \mathrm{g} /$ $\mathrm{ml}, 100 \mu \mathrm{g} / \mathrm{ml})$ in triplicate into clean and dried test tubes. Each tube contained $2 \mathrm{ml}$ rutin, $0.3 \mathrm{ml}$ of $5 \%(\mathrm{w} / \mathrm{v})$ $\mathrm{NaNO}_{2}, 0.3 \mathrm{ml}$ of $10 \% \mathrm{AlCl}_{3}$, and $2.0 \mathrm{ml}$ of $4 \% \mathrm{NaOH}$. The reaction mixture was incubated at room temperature for 15 minutes and the absorbance was read at $500 \mathrm{~nm}$ against the reagent blank. The standard calibration curve was prepared by plotting the absorbance against rutin and quercetin concentrations. The estimation of total flavonoid content in the extract was done by pipetting 1 $\mathrm{ml}$ and $2 \mathrm{ml}$ of $1 \mathrm{mg} / \mathrm{ml}$ of CCME. The volumes were adjusted to $2.0 \mathrm{ml}$ with distilled water, followed by the addition of $0.3 \mathrm{ml}$ of $5 \% \mathrm{NaNO}_{2}(\mathrm{w} / \mathrm{v}), 0.3 \mathrm{ml}$ of $10 \%$ $\mathrm{AlCl}_{3}(\mathrm{w} / \mathrm{v})$ and $2.0 \mathrm{ml}$ of $4 \% \mathrm{NaOH}(\mathrm{w} / \mathrm{v})$ to give a total volume of $3.6 \mathrm{ml}$. The reaction mixture was treated as above and the absorbance was read at $500 \mathrm{~nm}$ against the reagent blank. The total flavonoid concentration of CCME was interpolated from the standard calibration curve and expressed as mg rutin and quercetin equivalent per $g$ of extract (mg RE/ g extract and mg QE/g extract). 


\subsection{Assessment of In vitro Antioxidant Activity}

\subsubsection{DPPH Radical Scavenging Activity}

The DPPH radical scavenging activity of CCME was assayed according to the procedure of Blois [13] as reported by Cakir et al., [14]. The serial dilution of 3.125 $-50 \mu \mathrm{g} / \mathrm{ml}$ working concentration was made from 1.0 $\mathrm{mg} / \mathrm{ml}$ stock of standard ascorbic acid and CCME in clean and dried test tubes in triplicates. The volumes were adjusted to $1.0 \mathrm{ml}$ with $10 \mathrm{mM}$ acetate buffer $(\mathrm{pH}$ 5.5), after which $1.0 \mathrm{ml}$ of $0.3 \mathrm{mM}$ DPPH was added. The reaction mixture was properly mixed by inversion and then incubated in a dark chamber for 30 minutes. The control contained everything above except the sample replaced with an equal amount of acetate buffer. The absorbance was read at $517 \mathrm{~nm}$. The percentage free radical scavenging activities of the standard and extract were calculated from the percentage inhibition of DPPH using the expression:

$$
\mathrm{I}_{\mathrm{DPpH}} \%=\frac{A b s_{\text {control }}-A b s_{\text {test }}}{A b s_{\text {control }}} \times 100
$$

where $\mathrm{Abs}_{\text {control }}$ is the absorbance of the control (absence of extract) and $\mathrm{Abs}_{\text {test }}$ is the absorbance with extract and standard samples. The IDPPH\% was plotted against the sample concentration and a logarithmic regression curve was established in order to calculate the $\mathrm{IC}_{50}$ value.

\subsubsection{Reducing Power Assay}

The procedure of Oyaizu [15] was used for the assay of reducing power of CCME to reduce iron from the form (III) $\left(\mathrm{Fe}^{3+}\right)$ to the form (II) $\left(\mathrm{Fe}^{2+)}\right.$. Different concentrations $(50-300 \mu \mathrm{g} / \mathrm{ml})$ of the extracts $(1.0 \mathrm{ml})$ were mixed with $2.5 \mathrm{ml}$ of $0.2 \mathrm{M}$ phosphate buffer, $\mathrm{pH} 6.6$ and $2.5 \mathrm{ml}$ of $1 \%(\mathrm{w} / \mathrm{v})$ potassium ferricyanide $\left[\mathrm{K}_{3} \mathrm{Fe}(\mathrm{CN})_{6}\right]$. The mixtures were incubated at $500 \mathrm{C}$ for 20 minutes after which the tubes were cooled. Trichloroacetic acid $[2.5 \mathrm{ml}$ of $10 \%(\mathrm{w} / \mathrm{v})$ ] was added to each reaction mixture, vigorously shaken and centrifuged at $3000 \mathrm{rpm}$ for 10 minutes. The supernatant $(2.5 \mathrm{ml})$ was mixed with $2.5 \mathrm{ml}$ distilled water and $0.5 \mathrm{ml} \mathrm{FeCl}_{3}$. The absorbance was read at $700 \mathrm{~nm}$ after 10 minutes against the reagent blank which contained everything above except the sample replaced with an equal amount of distilled water. Ascorbic acid was used as the standard. The absorbance obtained was plotted against the different concentrations.

\subsubsection{Lipid Peroxidation Assay}

Lipid peroxidation assay was carried out on CCME according to the method of Ohkawa et al., [16] as described by Nabasree and Bratati [17] with 2, 6-Di-tert-butyl-4methylphenol (BHT) as a positive control. Typically, 0.5 $\mathrm{ml}$ of a $10 \%(\mathrm{v} / \mathrm{v})$ egg yolk homogenate in distilled water was added to $0.1 \mathrm{ml}$ of varying concentrations of the extract and standard BHT (1000, 500, 250, 125, 65.5, $31.25 \mu \mathrm{g} / \mathrm{ml}$ ) in a test tube followed by the addition of $1 \mathrm{ml}$ distilled water and $50 \mu \mathrm{l}$ of ascorbic acid $(1 \mathrm{mM})$. Then $50 \mu \mathrm{l}$ of $\mathrm{FeSO}_{4}(0.07 \mathrm{M})$ was added to the reaction mixture to induce lipid peroxidation. The mixture was vortexed and allowed to stand for 30 minutes at room temperature after which $1.5 \mathrm{ml}$ of $20 \%$ acetic acid and $1.5 \mathrm{ml}$ of $0.8 \%(\mathrm{w} / \mathrm{v})$ thiobarbituric acid in $1.1 \%$ sodium dodecyl sulphate were added. The resulting mixture was then heated in a water bath at $95^{\circ} \mathrm{C}$ for 1 hour. After cooling, $4.0 \mathrm{ml}$ of butan-1-ol was added to each tube and centrifuged at $3000 \mathrm{rpm}$ for 10 minutes. The control was run as above with extract replaced with distilled water. The absorbance of the organic upper layer was measured at $532 \mathrm{~nm}$. Percentage inhibition of lipid peroxidation was calculated as:

$$
\frac{A_{0}-A_{1}}{A_{0}} \times 100
$$

where $\mathbf{A}_{0}$ is the absorbance of the control (absence of extract) and $\mathbf{A}_{\mathbf{1}}$ is the absorbance with extract and standard samples.

\subsection{Assessment of In Vitro Anti-inflammatory Activi- ty}

\subsubsection{Human Red Blood Cell Membrane (HRBC) Sta- bilization Method}

The method as prescribed Sakat et al., [18] was adopted with some modifications. The blood was collected from a healthy human volunteer who had not taken any NSAIDS for 2 weeks prior to the experiment and mixed with an equal volume of Alsever solution ( $2 \%$ dextrose, $0.8 \%$ sodium citrate, $0.5 \%$ citric acid and $0.42 \% \mathrm{NaCl}$ ) and centrifuged at 3,000 rpm. The packed cells were washed with isosaline and a $10 \%$ suspension was made. Various concentrations of CCME $(100-1000 \mu \mathrm{g} / \mathrm{ml})$ were prepared using distilled water and to each concentration, 1 $\mathrm{ml}$ of phosphate buffer, $2 \mathrm{ml}$ hyposaline and $0.5 \mathrm{ml}$ of $\mathrm{HRBC}$ suspension were added. It was incubated at $37^{\circ} \mathrm{C}$ for 30 minutes and centrifuged at $3,000 \mathrm{rpm}$ for 20 minutes and the haemoglobin content of the supernatant solution was estimated spectrophotometrically at $560 \mathrm{~nm}$. Ibuprofen $(100-1000 \mu \mathrm{g} / \mathrm{ml})$ was used as a reference standard and control was prepared by omitting the extracts. The experiments were performed in triplicates and 
mean values of the three were considered. The percentage (\%) of HRBC membrane stabilization or protection is calculated using the following formula:

Percentage of Protection $(\%)=\left[100-\left(\frac{O D \text { of drug }- \text { treated sample }}{O D \text { of Control }}\right) \times 100\right]$

\subsubsection{Assay of Inhibition of Denaturation of Albumin}

The inhibition of denaturation of albumin of CCME was carried out according to the method of Mizushima and Kobayashi [20] with slight modification. Typically, 0.00, $0.15,0.30,0.45,0.60,0.75,0.90$ and $1.00 \mathrm{ml}$ of the extract $(0-350 \mu \mathrm{g} / \mathrm{ml})$ was pipetted separately into clean dried test tubes in triplicate. The volumes were adjusted to $2.50 \mathrm{ml}$ with $\mathrm{n}$-saline. Then, $0.5 \mathrm{ml}(0.25 \mathrm{mg} / \mathrm{ml})$ albumin was added to each of the test tubes, followed by incubation at $37^{\circ} \mathrm{C}$ for 20 minutes. The reaction mixture was later heated at $57{ }^{\circ} \mathrm{C}$ for 3 minutes. The tubes were cooled and $2.5 \mathrm{ml}$ of $0.5 \mathrm{M}$ phosphate buffer, $\mathrm{pH} 6.3$ was added. From each of the reaction mixtures, $1.0 \mathrm{ml}$ was pipetted into clean dried test tubes and $1.0 \mathrm{ml}$ of $0.25 \mathrm{mg} / \mathrm{ml}$ albumin also. Copper-Alkaline reagent $(1.0 \mathrm{ml})$ and $1.0 \mathrm{ml}$ of Folin-Ciocalteu's reagent (1:10) was added to each of the tubes. The reaction mixture was incubated at $55^{\circ} \mathrm{C}$ for 10 minutes the tubes were cooled and the absorbance was read at $650 \mathrm{~nm}$ against reagent blank. The amount of protein left in each of the fractions was calculated using the expression:

\section{$\frac{\text { Absorbance of test }- \text { Absorbance of blank }}{\text { Absorbance of standard - Absorbance of blank }} \times$ Concentration}

The percentage inhibition was calculated using the expression: $\frac{\text { Concentration of protein left }}{\text { Inital protein concentration }} \times 100$

\subsection{Statistical Analysis}

The results were expressed as Mean \pm SEM, $\mathrm{n}=3$ readings. Differences between mean values of sample and standard were determined by One-way ANOVA followed by Tukey multiple comparison test using GraphPad Prism 5. Differences were considered to be significant if $\mathrm{P}<0.05$.

\subsection{RESULTS}

\subsection{Phytochemical Screening}

The table below shows the result of the phytochemical screening carried out on CCME. The phytochemical screening of CCME revealed the presence of flavonoids, xanthoproteins, saponins, triterpenes, steroids, and tanins. However, phlobatanins and anthraquinone were not detected as shown in Table 1.

Table 1. Phytochemical Screening Result

\begin{tabular}{ll}
\hline Phytochemicals & Inference \\
Steroids & + \\
Tannins & + \\
Phlobatannis & - \\
Flavonoids & + \\
Saponins & + \\
Anthraquinone & - \\
Triterpenes & + \\
Xanthoproteins & + \\
\hline Key: Present $(+)$, Absent $(-)$ &
\end{tabular}

\subsection{Quantitative Analysis of Antioxidant Components Result}

\subsubsection{Estimation of TPH Concentration}

The total phenolic concentration in CCME using tannic acid as standard phenol was calculated to be 26.720 .048 $\mu \mathrm{gTAE} / \mathrm{mg}$ extract (tannic acid equivalent/mg of CCME).

\subsubsection{Estimation of TFL Concentration}

The total flavonoids concentration in CCME was quantified using both rutin and quercetin as flavonoids standard. The results are as shown in Table 2. The flavonoid quantity with rutin as a reference was higher than that of quercetin as standard.

Table 2. Quantification of Antioxidant Components

\begin{tabular}{ll}
\hline Antioxidant Components & Concentration \\
\hline Total Phenol Concentration & $26.72 \pm 0.05 \mu \mathrm{gTAE} / \mathrm{mg}$ extract \\
Total Flavonoid Concentration & $23.12 \pm 1.92 \mu \mathrm{gRE} / \mathrm{mg}$ extract \\
Total Flavonoid Concentration & $10.49 \pm 1.12 \mu \mathrm{gQE} / \mathrm{mg}$ extract \\
\hline
\end{tabular}

Each value represented Mean \pm SEM of $n=3$. TAE is tannic acid equivalent, $\mathrm{RE}$ is rutin equivalent, $\mathrm{QE}$ quercetin equivalent

\subsection{Assessment of In Vitro Antioxidant Assay}

\subsubsection{DPPH Radical Scavenging Activity}

The graphical representations of the result of the percentage inhibition of the DPPH radical scavenging 
Dare and Elvis Pan African Journal of Life Sciences (2020): 4(3): 127-136 activity of the standard ascorbic acid and CCME are shown in Figure 1. CCME competed favourably with ascorbic acid in scavenging DPPH radical at lower concentrations than at higher concentrations. Table 3 presented the $\mathrm{IC}_{50}$ values of ascorbic acid and CCME with that of CCME significantly higher than that of ascorbic acid. Figure 2 showed the graph of the result of CCME reducing power assay plotted with ascorbic acid standard. The ascorbic acid showed higher reducing capacities than CCME at all concentrations used.

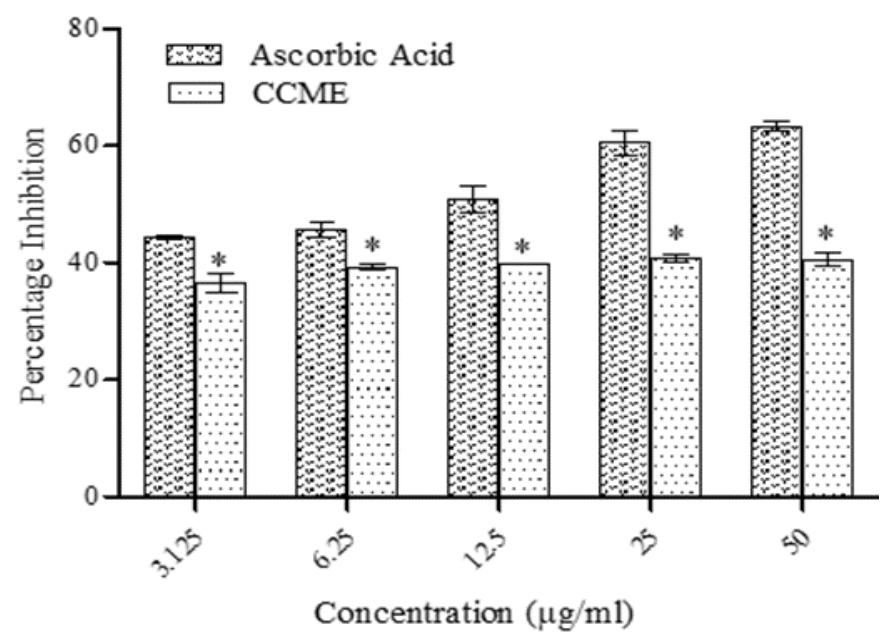

Figure 1. DPPH Radical Scavenging Activities of CCME and Ascorbic Acid. Each value represented Mean \pm SEM of $n=3$. CCME was compared with standard ascorbic acid. The values with an asterisk $\left(^{*}\right)$ are statistically significant at $\mathrm{P}<0.05$.

Table 3. $\mathrm{IC}_{50}$ Values of DPPH and CCME

\begin{tabular}{ll}
\hline Sample/Standard & $\mathbf{I C}_{\mathbf{5 0}}(\boldsymbol{\mu g} / \mathbf{m l})$ \\
\hline Ascorbic Acid & $45.61 \pm 2.84$ \\
CCME & $550.52 \pm 82.83 * * *$ \\
\hline
\end{tabular}

Lipid Peroxidation Inhibition of CCME and BHT. Each value represented Mean \pm SEM of $n=3$. CCME was compared with standard BHT. The values with an asterisk $\left(^{*}\right)$ are statistically significant at $\mathrm{P}<0.05$. Each value represented Mean \pm SEM of $\mathrm{n}=3$.

\subsubsection{Ferric Reducing Power Assay}

\subsubsection{Lipid Peroxidation Inhibition Assay}

The result of lipid peroxidation inhibition assay carried out on the CCME and standard BHT is shown in Figure 3. CCME competed favourably with the standard BHT used.

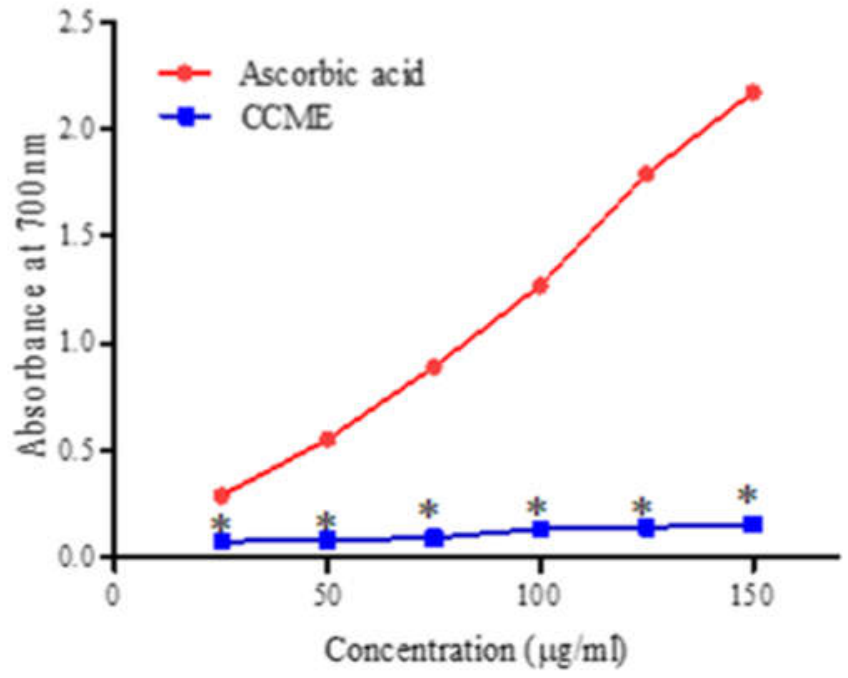

Figure 2. Reducing Power Activity of CCME and Ascorbic Acid . Each value represented Mean \pm SEM of $n=3$. CCME was compared with standard ascorbic acid. The values with an asterisk $(*)$ are statistically significant at $\mathrm{P}<0.05$.

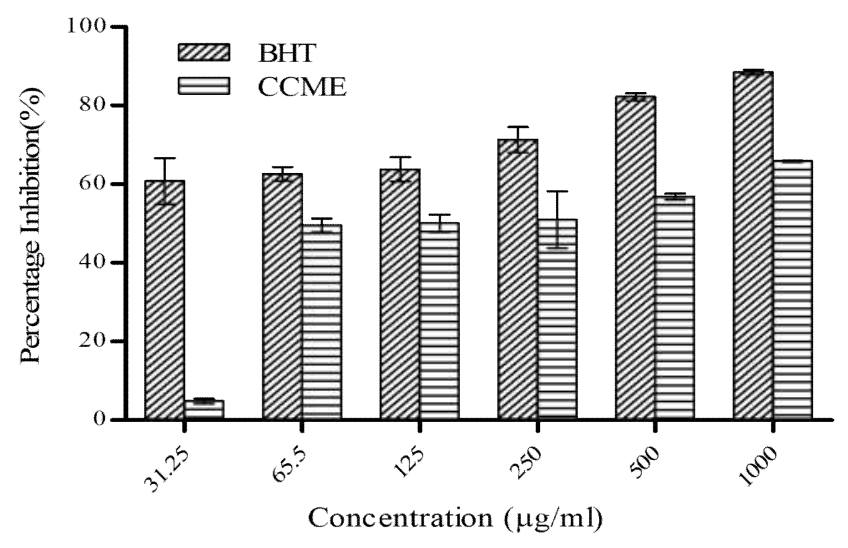

Figure 3: Lipid Peroxidation Inhibition of CCME and HT. Each value represented Mean \pm SEM of $n=3$. CCME was compared with standard BHT. The values with an asterisk $\left(^{*}\right)$ are statistically significant at $\mathrm{P}<0.05$.

\subsection{Assessment of In Vitro Anti-Inflammatory Assay}

\subsubsection{HBRC Stabilization Assay}

The result of the HBRC stabilization assay carried out on CCME and standard drug ibuprofen is presented in Figure 4. Both CCME and standard ibuprofen exhibited a biphasic mode of inhibition of red blood cell lysis.

\subsubsection{Result of Inhibition of Denaturation of Albumin Activity}

The result of the inhibition of denaturation of albumin by standard diclofenac and CCME were calculated by percentage inhibition and represented in Figure 5, with diclofenac with a higher inhibition potential than CCME at all concentrations used. 


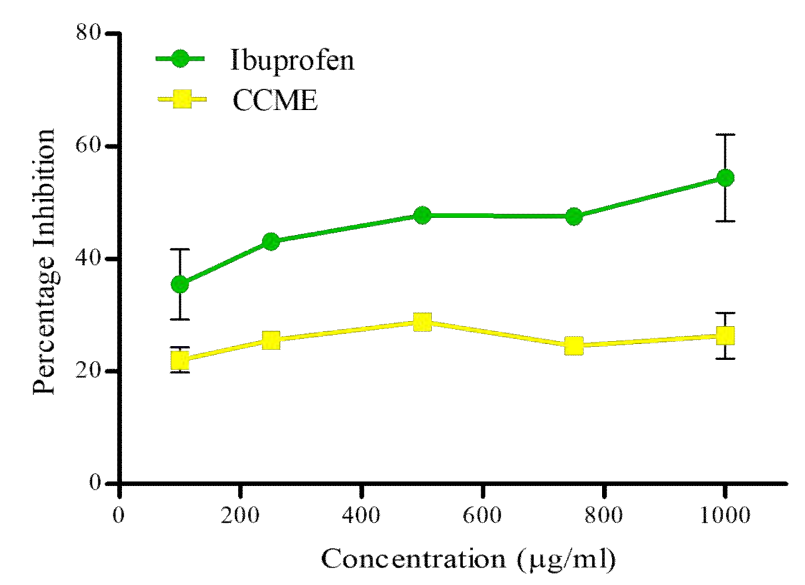

Figure 4. Membrane stabilisation Profile for CCME and Ibuprofen. Each value represented Mean \pm SEM of $n=3$. CCME was compared with standard Ibuprofen. The values with an asterisk $\left({ }^{*}\right)$ are statistically significant at $\mathrm{P}<0.05$.

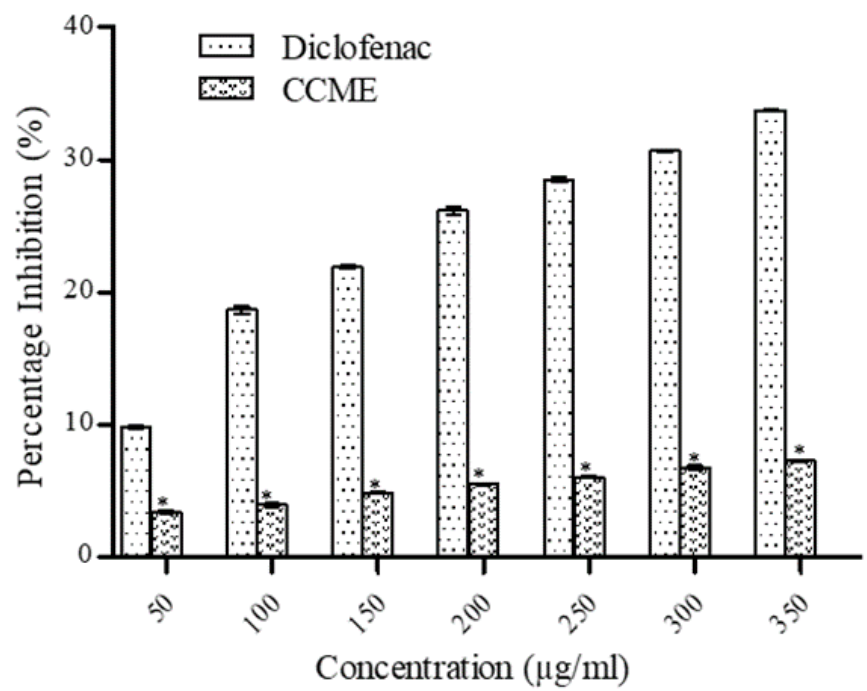

Figure 5. Albumin Denaturation Inhibition by CCME and Diclofenac. Each value represented Mean \pm SEM of $n=3$. CCME was compared with standard diclofenac. The values with asterisk $(*)$ are statistically significant at $\mathrm{P}<0.05$.

\subsection{DISCUSSION}

The screening of the phytochemical constituents of CCME indicated the presence of tannins, flavonoid, saponin, triterpenes and xanthoproteins. The presence of these secondary metabolites most of which has been proven to have antioxidant potentials suggested that $C$. albidum cotyledon might be of great importance in phytomedicines development. Natural secondary metabolites have been proven to be mostly multifunctional, mostly the polyphenols [21,22]. For example, tannin, flavonoid, saponin have been reported to exhibit anti-microbial, antioxidant, anti-inflammatory, antinociceptive, antidiarrhoeal and anti-allergic activities [23,24]. Tannins act as iron-depriver and interact with specific protein and enzymes in microbial cells [25]. It has also been suggested that tannins and some other phytochemicals have remarkable activity in the treatment of cancer, thus good anticancer agents [26]. Hence, plant-derived supplements can be useful in the maintenance of good health and combating degenerative diseases including cancer $[27,28]$. From this research, CCME exhibited a significant scavenging effect on DPPH radical between 10-150 $\mu \mathrm{g} / \mathrm{ml}$ and compared well with standard ascorbic acid though showing less scavenging activity with $\mathrm{IC}_{50}$ of $550.5282 .83 \mu \mathrm{g} / \mathrm{ml}$. The DPPH scavenging activity has been shown to be correlated with the phenolic concentration of the extract (as shown in Tables 1 and 2) [29, 30] which is believed to contribute their electron transfer/ hydrogen donating ability. The flavonoid composition of the extract (Table 2) has hydroxyl group that could stabilize free radical and scavenge their activity.

In this present study, CCME was able to reduce the $\mathrm{Fe}^{3+}$ / ferricyanide to ferrous form, $\mathrm{Fe}^{2+}$, which can be measured as the formation of Perl's Prussian blue colour measured at $700 \mathrm{~nm}[31,32]$. The extract could be said to be potent as a good electron and hydrogen donor which can react with free radicals to convert them to a more stable product and terminate the chain reaction although it didn't compare favourably with that of standard ascorbic acid. Several studies have also reported the reducing power activity of several plants extracts $[33,34,35]$, and this has been linked to the polyphenols constituents of these extracts.

Lipid peroxidation is one of the consequences of reactive oxygen species (ROS) and free radicals. In this study, lipid peroxidation was induced by $\mathrm{FeSO}_{4}$, a free radical initiator. Thermal decomposition of $\mathrm{FeSO}_{4}$ produces radicals which can attack polyunsaturated lipid to produce lipid peroxidation. The methanol extract of $C$. albidum cotyledon significantly inhibited $\mathrm{Fe}^{2+}$-induced lipid peroxidation within $45.85 \%$ - $65.85 \%$ while BHT showed greater ability within $62.61 \%-88.45 \%$. Lipid peroxidation in the cell leads to direct damage of the cell membranes with indirect damages of other cell constituents, caused by the reactivity of the secondary product of this reaction, aldehydes (malondialdehyde). This complex reaction is responsible for the damage of many tissues and progression of some disease (e.g. atherosclerosis) 
$[36,37]$.

Stabilization of the membrane of the human red blood cells inhibits lysis and subsequent release of the cytoplasmic contents which in turn limits tissue damage and exacerbation of the inflammatory response $[38,39]$. It is therefore expected that compounds with membrane stabilization activity should offer significant protection of cell membrane against injurious substances [40, 41]. Methanol extract of $C$. albidum cotyledon showed less inhibition through $50-350 \mu \mathrm{g} / \mathrm{ml}$ with percentage protection of $22.06 \%-26.37 \%$ compare to Ibuprofen with percentage protection of $35.47 \%-54.40 \%$. Both ibuprofen and CCME showed a biphasic mode of membrane stabilising potential. This suggests that the extract has a significant protective effect on haemolysis induced by free radicals because it has the ability to donate hydrogen atom and terminate peroxidation. The assay on inhibition of albumin denaturation showed that CCME inhibited the denaturation of albumin but not favourably compared with standard ibuprofen from $50-350 \mu \mathrm{g} / \mathrm{ml}$ having $0.08-0.54 \mu \mathrm{g} / \mathrm{ml}$ of total amount of protein left and $3.42-7.32 \%$ percentage inhibition while the standard has $0.81-3.69 \mu \mathrm{g} / \mathrm{ml}$ of protein left and $9.82-$ $33.75 \%$ percentage inhibition. In albumin denaturation assay, the denaturation is induced by heat treatment. The denaturation of proteins is well documented and is caused by an inflammation process, mostly in conditions like arthritis [42]. Inflammation is a normal biological response of the cells to injury but could also be detrimental to the cell when it is provoked at other instances.

In conclusion, this study showed that $C$. albidum cotyledon methanol extract is a potent antioxidant and antiinflammatory agent on oxidative stress and inflammation caused by reactive species that were investigated in vitro. The observation concerning the diversity and complexity of the phytochemical in plant extract with different mechanisms for antioxidant and antiinflammation specific for each reactive species applies very well to this present study. There is a correlation between the total phenolic/flavonoid content and the antioxidant and anti-inflammatory of the plant extract indicating the various antioxidant and anti-inflammation are based on the phenol and flavonoid content. It could, therefore, be inferred that the activities of methanol extract is due to the phenols and flavonoids. Therefore, the methanol extract (CCME) could be recommended as a potential antioxidant to ameliorate oxidative and free radical-induced pathologies.

\section{Conflict of Interest}

The authors declare that there is no conflict of interest.

\section{Authors Contribution}

CAD conceived and designed the study, contributed to data analysis tools, performed data analysis and manuscript writing; NOE Performed data collection, contributed to data analysis tools and writing of manuscript

\section{References}

1. Edeoga HO, Okwu DE, Mbaebie BO. Phytochemical constituents of some Nigerian medicinal plants. African Journal of Biotechnology. 2005; 4: 685-688.

2. Suleiman MHA, Brima EI. Phytochemicals, trace element contents, and antioxidant activities of bark of Taleh (Acacia seyal) and desert rose (Adenium obesum). Biological Trace Elements Research. 2020; 12011: 020-024.

3. Dahanukar SA, Kulkarni RA, Rege NN. Pharmacology of medicinal plants and natural products. Indian J. Pharmacol. 2000; 32(4): 81-118.

4. Soltanian S, Sheikhbahael M, Mirtadzadini M. and, Khandani B. Evaluation of anticancer, antioxidant and antibacterial properties of methanol extract of three Acantholimon Boiss species. Avicenna Journal of Phytomedicine. 2020; 10(6): 641-652.

5. Patwardhan B, Vaidya ABD, Chorghade M. Ayurveda and natural products drug discovery. Current Science. 2004; 86(6): 789-799.

6. Rana D, Bhatt A, Lal B, Parkash O, Kumar A, Uniyal S. Use of medicinal plants for treating different ailments by the indigenous people of Churah subdision of district Chamba, Himachal Pradesh, India. Environment, Development and Sustainability. 2020; 1-80.

7. Rysz J, Franczyk B, Lawinski J, Gluba-Brzozka A. Oxidative stress in ESRD patients on dialysis and the risk of cardiovascular diseases. Antioxidants. 2020; 9(11): 1079 -1082 .

8. Sofowora A. Medicinal plants and traditional medicine in Africa. Spectrum Books Ltd., Ibadan; 1993. p. 191-289.

9. Oyedapo OO, Adeoye BA. Toxicity of Erythrophleum guineense stem-bark: role of alkaloidal fraction. African Journal of Traditional, Complementary and Alternative Medicines. 2004; 1: 45-54. 
10. Trease GE, Evans SM. Pharmacognosy, 15th edn. Bailer Tindal, London; 2002. p. 23-67.

11. Singleton VL, Orthofera R, Lamuela RRM. Analysis of total phenols and other oxidation substrates and antioxidants by means of Folin-Ciocalteaus reagent. Methods in Enzymol. 1999; 299: 152-179.

12. Sun PX, Yie LK, Zhang ZL, Hu M, Lu L. Colorimetric determination of the total content of the flavonoids in epimedium capsules. J. Shenyang Pharmaceut. Univ. 1999; 16: $68-70$.

13. Blois MS. Antioxidant determinations by use of stable free radicals. Nature. 1985; 181: 1199-1200.

14. Cakir A, Mari A, Yildinn A, Duru ME, Harmender M, Kazaz C. Isolation and characterization of antioxidant phenolic compounds from the aerial parts of Hypericum hyssopifolium, L. by activity guided fractionation. J. Ethnopharmacol. 2003; 87: 73-83.

15. Oyaizu M. Studies on products of browning reaction prepared from glucosamine. Japanese Journal of Nutrition. 1986; 44: 307-315.

16. Ohkawa H, Ohishi N, Yagi K. Assay for lipid peroxides in animal tissues by thiobarbituric acid reaction. Anal Biochem. 1979; 95: 358.

17. Nabasree D, Bratati D Antioxidant activity of Piper betle L. leaf extract in vitro. Food Chemistry. 2004; 88(2): 219224.

18. Sakat SS, Juvekar AR, Gambhire MN. In vitro antioxidant and anti-inflammatory activity of methanol extract of Oxalis corniculata Linn. International Journal of Pharmacy and Pharmaceutical Sciences. 2010; 2(1): 146-155.

19. Mizushima $\mathrm{Y}$, Kobayashi M. Interaction of antiinflammatory drugs with serum proteins, especially with some biologically active proteins.J Pharm Pharmacol. 1968; 20(3): 169-173.

20. Nabasree D, Bratati D Antioxidant activity of Piper betle L. leaf extract in vitro. Food Chemistry. 2004; 88(2): 219224.

21. Fu L, Xu BT, Xu XR, Gan RY, Zhang Y, Xia EQ, Li HB. Antioxidant capacities and total phenolic contents of 62 fruits. Food Chemistry. 2011; 129(2): 345-350.

22. Mannino G, Perrone A, Campobenedetto C, Schittone A, Bertea CM, Gentile C. Phytochemical profile and antioxidative properties of Plinia trunciflora fruits: a new source of nutraceuticals. Food Chemistry. 2020; 307: 125515.

23. Idowu TO, Ogundaini AO, Adesanya SA, Onawunmi GO, Osungunna MO, Obuotor EM, Abegaz BM. Isolation and characterization of chemical constituents from Chrysophyl- lum albidum g. Don-holl. stem-bark extracts and their antioxidant and antibacterial properties. Afr J Tradit Complement Altern Med. 2016; 13(5): 182-189.

24 Talla RM, Jouda J, Mawabo IK, Tegasne C, Happi GM, Lenta BN, Kapche G, Frese M, Wandji J, Sewald N. Chemical constituents of the fruits of Gambeya lacourtiana (Sapotacea). Phytochemistry Letters. 2020; 38: 84-89.

25. McRae JM, Kennedy JA. Wine and grape tannin interactions with salivary proteins and their impact on astringency: A review of current research. Molecules. 2011; 16: 2348-2364.

26. Dutt P, Garg V, Khatri N, Madan AK. Phytochemicals in anticancer drug development. Anti-Cancer Agents in Medicinal Chemistry. 2019; 19(2): 172-183.

27. Demiray S, Pintado ME, Castro PML. Evaluation of phenolic profiles and antioxidant activities of Turkish medicinal plants: Tilia argentea, Crataegi folium leaves and Polygonum bistorta roots. World Academy of Science, Engineering and Technology. 2009; 54: 312-317.

28. Ahmad M, Mohammad N, Aziz M, Alam A, Hossain S, Islam R, Uddin G. Comparison of antioxidant role of methanol, acetone and water extracts of Andrographis paniculata Nees. Journal of Medicinal Plants and Research. 2020; 14(8): 428-437.

29. Manian R, Anusuya N, Siddhuraju P, Manian S. The antioxidant activity and free radical scavenging potential of two different solvent extracts of Camellia sinensis (L.) O. Kuntz, Ficus bengalensis L. and Ficus racemosa L. Food Chem. 2008; 107: 1000-1007.

30. Akinmoladun AC, Obuotor EM, Farombi EO. Evaluation of Antioxidant and Free radical scavenging capacities of some Nigerian Indigenous medicinal plants. J Med Food. 2010; 13(2): 1-8.

31. Chung YC, Chang CT, Chao WW, Lin CF, Chou ST. Antioxidant activity and safety of the $50 \%$ ethanolic extract from red bean fermented by Bacillus subtilis IMR-NKI. J. Agric. Food Chem. 2002; 50: 2454-2458.

32. Wafa N, Sofiane N. In vitro antioxidant, antimicrobial, and anti-inflammatory activities development of methanol extract of Cyclamen africanum B. et R., growth in JijelAlgeria. Journal of Drug Delivery and Therapeutics. 2020; 10(1-s): 135-139.

33. Manian R, Anusuya N, Siddhuraju P, Manian S. The antioxidant activity and free radical scavenging potential of two different solvent extracts of Camellia sinensis (L.) O. Kuntz, Ficus bengalensis L. and Ficus racemosa L. Food Chem. 2008; 107: 1000-1007. 
34. Sen S, De B, Devanna N, Chakraborty R. Total phenolic, total flavonoid content, and antioxidant capacity of the leaves of Meyna spinosa Roxb., an Indian medicinal plant. Chin J Nat Med. 2013; 11(2): 149-157.

35. Rahman MM, Habib MR, Hasan MA, Al Amin M, Saha A, Mannan A. Comparative assessment on in vitro antioxidant activities of ethanol extracts of Averrhoa bilimbi, Gymnema sylvestre and Capsicum frutescens. Pharmacognosy Res. 2014; 6(1): 36-41.

36. Sakac V, Sakac M. Free oxygen radicals and kidney diseases. Medicinski pregled. 2000; 53(9-10): 463-74.

37. Jabbar U, Mahmood M, Javed A, Nizami N, Mushtaq M, Qureshi J. Assessment of health status in fiber glass workers: role of chromium with biological antioxidants. The Professional Medical Journal. 2020; 27(06): 1206-1211.

38. Okoli CO, Akah, PA, Onuoha NJ, Okoye, TC, Nwoye AC, Nworu CS. Acanthus montanus: An experimental evaluation of the antimicrobial, anti-inflammatory and immunological properties of a traditional remedy for furuncles. BMC Complementary. Alternative Medicine. 2008; 8: 27.
39. Ikechukwu U, Ikechukwu E, Ani O, Paulinus N, Adeyi S, Ukamaka E. Methanol extract of Acanthus Montanus (Acanthaceae) leaves ameliorates oxidative stress and improves haematological indices in rats. African Journal of Pharmaceutical Research and Development. 2020; 12(1): 026-037.

40. Umapathy EU, Ndebia EJ, Meeme A, Adam B, Menziwa $\mathrm{P}$, Nkeh-Chungag BN, Iputo JE. An experimental evaluation of Albuca setosa aqueous extract on membrane stabilization, protein denaturation and white blood cell migration during acute inflammation. Journal of Medicinal Plant Research. 2010; 4(9): 789-795.

41. Xiao S, Yu H, Xie Y, Guo Y, Fan J, Yao W. The antiinflammatory potential of Cinnamomum camphora (L.) J. Presl essential oil in vitro and in vivo. Journal of Ethnopharmacology. 2020; 113516.

42. Mangoale R, Afolayan A. Comaparative phytochemical constituents and antioxidant activity of wild and cultivated Alepidea amatymbica Eckl and Zeyh. BioMed Research International. 2020; 2020: 1-13. 